\title{
PEMBELAJARAN KOOPERATIF DENGAN PENDEKATAN EXPERIENTAL LEARNING UNTUK MENINGKATKAN KETERAMPILAN SOSIAL
}

\author{
Jenny Indrastoeti ${ }^{1}$, SP, \& Hasan Mahfud ${ }^{2}$ \\ 1,2PGSD FKIP Universitas Negeri Sebelas Mare† \\ $1,2 \mathrm{Jl}$. Slamet Riyadi No 449 Surakarta \\ 'Email: yenny_pgsd@yahoo.co.id \\ 2Email: hasanmahfud449@gmail.com
}

\begin{tabular}{|c|c|}
\hline ABSTRACT & ABSTRAK \\
\hline $\begin{array}{l}\text { The purpose of this research is (1) to improve the } \\
\text { social skill of elementary school students, (2) } \\
\text { finding adequate instructional design model to } \\
\text { improve students' social skill. The research is } \\
\text { conducted in the classroom action research } \\
\text { consists of two cycles, every cycle consists of } \\
\text { planning, action, observation, and reflection. The } \\
\text { average value of Social Skills students in cycle } \\
\text { one is } 62.01 \text { and } 72.52 \text { in the two cycles. The } \\
\text { values percentage in the classical mastery of } \\
\text { social skills is } 40 \% \text { in cycle } 1 \text { and } 85.85 \% \text { in cycle } 2 \text {. } \\
\text { Based on the result, the conclusions are: 1) Model } \\
\text { cooperative learning with experiential learning } \\
\text { approach, can improve students' social skills. (2) } \\
\text { Instructional design to improve the social skills of } \\
\text { students in learning social studies is a model of } \\
\text { cooperative learning with experiential learning } \\
\text { approach } \\
\text { Keywords: cooperative model, experiental } \\
\text { learning, social skill. }\end{array}$ & $\begin{array}{l}\text { Tujuan dari penelitian ini adalah untuk (1) } \\
\text { meningkatkan keterampilan sosial siswa sekolah } \\
\text { dasar, (2) menemukan model desain } \\
\text { pembelajaran yang memadai untuk } \\
\text { meningkatkan keterampilan sosial siswa. Model } \\
\text { penelitian yang digunakan adalah penelitian } \\
\text { tindakan kelas yang yang terdiri dari dua siklus, } \\
\text { masing-masing siklus memuat perencanaan, } \\
\text { tindakan, observasi dan refleksi. Hasilnya adalah } \\
\text { sebagai berikut: (1) rata-rata keterampilan sosial } \\
\text { siswa pada siklus } 1 \text { adalah } 62,01 \text { dan } 72,52 \text { pada } \\
\text { siklus 2. Persentase nilai keterampilan sosial siswa } \\
\text { adalah 40\% pada siklus 1, dan 85,85\% pada siklus } \\
2 \text { Berdasarkan hasil tersebut, disimpulkan } \\
\text { bahwa: (1) model pembelajaran kooperatif } \\
\text { dengan pendekatan experiental learning dapat } \\
\text { meningkatkan keterampilan sosial siswa, (2) salah } \\
\text { satu desain instruksional untuk meningkatkan } \\
\text { keterampilan sosial siswa adalah dengan } \\
\text { pembelajaran kooperatif yang menggunakan } \\
\text { experiental learning }\end{array}$ \\
\hline & $\begin{array}{l}\text { Kata kunci: model kooperatif, experiental } \\
\text { learning, keterampilan sosial. }\end{array}$ \\
\hline
\end{tabular}

How to Cite: Indrastoeti, J., \& Mahfud, H. (2015). PEMBELAJARAN KOOPERATIF DENGAN PENDEKATAN EXPERIENTAL LEARNING UNTUK MENINGKATKAN KETERAMPILAN SOSIAL. Mimbar Sekolah Dasar, 2(2), $140-151$. doi:http://dx.doi.org/10.17509/mimbar-sd.v2i2.1325.

PENDAHULUAN IImU pengetahuan sosial (IPS) merupakan salah satu pelajaran yang diajarkan pada anak di sekolah dasar. Pelajaran ini mengajarkan, jika kita tinjau secara mendalam maka akan mengajarkan pada anak tentang berbagai macam hal yang berguna nanti dalam kehidupannya. IPS (social studies) adalah ilmu-ilmu sosial yang disederhanakan untuk tujuan-tujuan pendidikan dan pengajaran di sekolah dasar dan menengah. Pembelajaran IPS di sekolah dasar adalah membina anak didik menjadi warga negara yang baik, memiliki pengetahuan, keterampilan dan kepedulian sosial dan dunia

(Sumaatmadja, 2006).

Di dalam Kurikulum Tingkat Satuan Pendidikan (KTSP, 2006) ditegaskan bahwa 
Jenny Indrastoeti, SP, \& Hasan Mahfud, Pembelajaran Kooperatif...

melalui mata pelajaran IPS peserta didik diarahkan untuk dapat menjadi warga negara Indonesia yang demokratis dan bertanggung jawab serta warga dunia yang cinta damai. Fenomena kehidupan global di masa mendatang yang penuh dengan tantangan, menuntut mata pelajaran IPS untuk dirancang bisa mengembangkan pengetahuan, pemahaman, dan kemampuan analisis terhadap kondisi sosial masyarakat dalam memasuki kehidupan bermasyarakat yang dinamis.

Jarolimek (2002, p. 8) mengharapkan bahwa pendidikan pengetahuan sosial hendaknya mampu mengembangkan aspek pengetahuan dan pemahaman (knowledge and understanding), aspek sikap dan nilai (attitude and value) serta aspek keterampilan (skill) pada diri siswa. Aspek pengetahuan dan pemahaman berkaitan dengan pemberian bekal pengetahuan dan pemahaman siswa tentang dunia dan kehidupan masyarakat di sekitarnya, aspek sikap berkaitan dengan pemberian bekal mengenai dasar-dasar etika dan norma yang nantinya menjadi orientasi nilai dalam kehidupanannya di masyarakat. Sedangkan aspek keterampilan meliputi keterampilan sosial (social skill) dan keterampilan intektual (intellectual skill) agar siswa tanggap terhadap permasalahan sosial di sekitarnya dan mampu bekerjasama dengan orang lain dalam kehidupan sehari-hari.
Keterampilan sosial diarahkan agar para siswa mampu hidup dan bekerjasama, berperan serta, menghormati hak orang lain, memiliki kepekaan sosial serta mampu mengendalikan diri dalam kehidupan sosialnya. Keterampilan ini dikembangkan melalui kegiatan-kegiatan yang bersifat kooperatif. Kegiatan kooperatif yang dilakukan bisa dalam bentuk diskusi kelompok yang dapat melatih siswa berinteraksi, berpartisipasi, bekerjasama, bertukar pengetahuan, pengalaman serta dapat mengembangkan nilai-nilai sosial serta dapat mengembangkan keterampilan sosial.

Beberapa temuan penelitian dan pengamatan yang telah dilakukan, dari segi hasil atau dampak pembelajaran IPS terhadap kehidupan bermasyarakat, masih belum begitu tampak. Perwujudan nilai-nilai sosial yang dikembangkan di sekolah belum tampak dalam kehidupan sehari-hari di masyarakat, keterampilan sosial para lulusan pendidikan dasar khususnya masih memprihatinkan, partisipasi dalam berbagai kegiatan kemasyarakatan semakin berkurang.

Sudah cukup banyak hasil penelitian yang memberikan simpulan bahwa pelaksanaan pembelajaran IPS sangat menjemukan karena penyajiannya bersifat monoton dan ekspositoris sehingga siswa kurang antusias dan membuat pembelajaran kurang menarik. Oleh karena itu, Sumaatmadja (dalam Syaodih, 2007, p. 11) menyatakan bahwa 
guru IPS wajib berusaha secara optimum menumbuhkan minat dan motivasi siswa untuk keberhasilan pembelajaran IPS.

Selanjutnya menurut Como \& Snow (dalam Syafruddin, 2001, p. 3), model pembelajaran IPS yang diimplementasikan saat ini masih bersifat konvensional, belum banyak menyentuh aspek afektif maupun psikomotor.

Berdasarkan hasil pemantauan peneliti, di SDN Tegalmulyo berdasarkan pengamatan yang dilakukan saat ini, masih lebih menekankan aspek kebutuhan formal daripada kebutuhan real siswa sehingga proses pembelajaran belum berlangsung optimal. Hal ini juga terlihat pada keterampilan bekerjasama dalam diskusi kelompok, sebagian siswa enggan bahkan tidak mau bertanya, menyampaikan saran dan yang bekerja terbatas hanya ketua kelompok saja. Di samping itu juga, penekanan output pembelajaran IPS saat ini cenderung pada aspek kognitif, untuk aspek afektif dan keterampilan sosial kurang mendapat porsi yang seimbang. Untuk meningkatkan keterampilan sosial siswa dalam pembelajaran IPS di sekolah dasar tersebut, perlu dikembangkan strategi pembelajaran IPS yang dapat menumbuhkan keterampilan sosial, melalui model pembelajaran kooperatif dengan pendekatan experiental learning.

Pendekatan experiental learning adalah pendekatan melalui pengalaman atau belajar dengan mengalami sendiri (Kolb, 2013). Pengalaman belajar merujuk kepada interaksi antara siswa dengan segala sesuatu yang berada di luar dirinya (siswa) di lingkungannya. "The learning that takes place from this experience is known as experiential learning" (Hasil belajar yang diperoleh dari pengalaman ini dikenal dengan sebutan "berpengetahuan dari pengalaman").

Sehubungan dengan itu, Cohen \& Deer (dalam Fernandes, et al., 1989, p. 40) menerangkan bahwa experiental learning mencakup content maupun proses: what is learned and how is learned". Pengalaman belajar mencakup isi dan proses, dalam hal ini belajar tidak hanya sekedar apa yang dipelajari namun bagaimana mempelajarinya.

Sukmadinata (2004, p. 60) menyatakan bahwa ada tiga macam keterampilan, yaitu "keterampilan intelektual, keterampilan sosial dan keterampilan motorik'. Secara umum keterampilan sosial merupakan kecakapan untuk hidup bermasyarakat.

Com \& Slaby (dalam Syaodih, 2007, p. 50) menjelaskan bahwa keterampilan sosial adalah kemampuan berinteraksi dengan orang lain dalam konteks sosial dengan cara yang spesifik sehingga dapat diterima atau dinilai menguntungkan bagi dirinya atau orang lain. Sementara itu, Sasongko (2001, p. 57) berpendapat bahwa keterampilan sosial diwujudkan 
Jenny Indrastoeti, SP, \& Hasan Mahfud, Pembelajaran Kooperatif...

dalam bentuk kemampuan individu dalam mengungkapkan perasaannya, baik positif maupun negatif saat berhubungan dengan orang lain secara verbal maupun nonverbal.

Blanks (2001) melihat keterampilan sosial disebut dengan keterampilan kelompok, berkaitan, baik sebagai pemimpin maupun yang dipimpin:

The ability to perform effectively both as a leader and as a follower in solving group problems, to participate in group resesrch projects to help set group goals, to use power effectively and fairly in group situations, to make useful contributions to group project, to communicate effectively in a group and to help resolve controversy in groups.

Keterampilan sosial seseorang terlihat ketika berinteraksi dengan orang lain, khususnya dalam kegiatan yang bersifat kelompok. Seseorang yang memiliki keterampilan sosial yang tinggi akan mampu dalam bekerja kelompok, berpartisipasi dan memberi kontribusi dalam mencapai tujuan kelompok, aktif memberikan saran yang bermanfaat dan berusaha memecahkan permasalahan. Walaupun keterampilan sosial lebih tampak sebagai kemampuan berinteraksi secara kelompok, tetapi berpangkal pada kemampuan personal masing-masing anggotanya. Kekuatan dan keterampilan masing-masing personal terintegrasi dalam kegiatan kelompok dan merupakan kekuatan kelompok.
Jarolimek (2002, p. 9) merumuskan keterampilan-keterampilan sosial yang dikembangkan pada tingkat sekolah dasar, yaitu: "1) living and working together, taking turns, respecting the rights of others, being social sensitive, 2) Learning self-control and self-direction, 3) sharing ides and experiences with others". Rumusan tersebut jika disederhanakan secara garis besar keterampilan sosial adalah kemampuan bekerjasama dengan orang lain secara positif, dalam kegiatan sosial.

Keterampilan ini dikembangkan melalui kegiatan-kegiatan yang bersifat kooperatif dalam kelompok yang banyak memberikan kesempatan kepada para siswa untuk berinteraksi, berpartisipasi, bertukar pengetahuan, pengalaman, nilai, serta pengembangan keterampilan dan sikap. Pembelajaran kooperatif dapat dirancang, baik untuk pengembangan keterampilan sosial, peningkatan pemahaman konsep-konsep dan masalah-masalah sosial, maupun nilai-nilai sosial.

Dalam pelaksanaan pembelajaran kooperatif dapat dilaksanakan melalui permainan, pengerjaan tugas, simulasi, tanya-jawab, diskusi, pemecahan masalah yang dikerjakan dalam kelompok berfungsi meningkatkan keterampilan sosial: keterampilan berinteraksi, bekerja sama, memimpin, berkontribusi, bertukar pendapat dan berbagi pengalaman. 
Keterampilan sosial yang dapat dipraktikkan dalam kehidupan siswa sehari-hari melalui model kooperatif, sebenarnya berhubungan dengan keterampilan intelektual atau kemampuan kognitifnya. Dalam hal ini sering tidak bisa dibedakan dengan jelas antara keterampilan intelektual dengan keterampilan sosial, karena memang saling berhubungan erat. Misalnya, kalau siswa sedang belajar kelompok dia tidak hanya terampil mengemukakan ide-ide dan gagasannya namun juga harus menghargai pendapat sesama anggota kelompoknya dan mengutamakan musyawarah mufakat dalam mengambil keputusan.

Jika keterampilan sosial diterapkan di luar kegiatan sekolah, misalnya ketika siswa berada ditempat umum dia tidak hanya mengetahui bagaimana harus menjaga kebersihan namun juga mempraktikkannya dalam kenyataan kehidupannya, sebagai contoh membuang sampah pada tempatnya. Dengan demikian siswa memiliki rasa tanggung jawab dalam melaksanakan apa yang menjadi kewajibannya dalam kehidupan nyata, sebagai hasil dari perilaku belajar yang diperolehnya melalui pembelajaran di sekolah.

$\begin{array}{llr}\text { Dibandingkan } & \text { dengan } & \text { model } \\ \text { pembelajaran konvensional, maka } & \\ \text { pembelajaran kooperatif } & \text { memiliki } \\ \text { beberapa kelebihan, terutama berkenaan } \\ \text { dengan pengembangan kemampuan }\end{array}$ dan keterampilan sosial siswa. Pembelajaran kooperatif memberi peluang yang besar kepada siswa untuk lebih aktif, mencari, mengkaji, mengemukakan pendapat, pengalaman, dan memadukan pandanganpandangan tersebut menjadi pandangan kelompok.

Menurut Hasan (Solihatin, 2009, p. 4), kooperatif mengandung pengertian bekerja bersama dalam mencapai tujuan bersama. Menurut Rusman (2010, p. 202), pembelajaran kooperatif (cooperative learning) merupakan bentuk pembelajaran dengan cara siswa belajar dan bekerja dalam kelompok-kelompok kecil secara kolaboratif yang anggotanya terdiri dari empat sampai enam orang dengan struktur kelompok yang bersifat heterogen.

Berdasarkan fenomena dan paparan teori di atas, dirumuskan permasalahan sebagai berikut: (1) Apakah dengan menggunakan model pembelajaran kooperatif dengan pendekatan experiental learning dapat meningkatkan keterampilan sosial siswa SDN kelas $V$ Tegal Mulyo Surakarta? (2) Bagaimana model desain pembelajaran yang memadai untuk meningkatkan keterampilan sosial siswa SDN kelas $\vee$ Tegal Mulyo Surakarta?

\section{METODE}

\section{Desain dan Prosedur Penelitian}

Jenis penelitian yang digunakan adalah 
Jenny Indrastoeti, SP, \& Hasan Mahfud, Pembelajaran Kooperatif...

penelitian tindakan kelas. Prosedur yang dilaksanakan dalam penelitian tindakan kelas ini berbentuk siklus, yang berlangsung selama dua siklus. Masingmasing siklus terdiri dari dua pertemuan. Adapun prosedur penelitian yang dipilih yaitu dengan menggunakan model spiral dari Kemmis dan Mc Taggart. Siklus model Kemmis dan Mc Taggart ini dilakukan secara berulang dan berkelanjutan, yang terdiri dari, perencanaan-pelaksanaan-observasi dan refleksi. Langkah-langkah pada model siklus Kemmis dan Taggart di atas yaitu sebagai berikut.

\section{Perencanaan tindakan}

Tahap ini mencakup semua perencanaan tindakan seperti pembuatan rencana pelaksanaan pembelajaran yang akan diterapkan, menyiapkan metode, alat dan sumber pembelajaran serta merencanakan langkah-langkah dan tindakan yang akan dilakukan untuk meningkatkan keterampilan sosial.

Dalam tahap ini penulis menetapkan seluruh rencana tindakan yang akan dilakukan untuk memperbaiki praktik pembelajaran mengenai materi peninggalan-peninggalan sejarah yang bercorak Hindu-Budha dan Islam yaitu dengan menerapkan: pembelajaran Kooperatif adapun langkah-langkah perencanaannya yaitu: 1) Meminta izin kepada kepala sekolah dan guru SD kelas V. 2) Membuat rencana pelaksanaan pembelajaran. 3) Merumuskan langkah- langkah dan tindakan yang akan dilakukan. 4) Memilih prosedur evaluasi penelitian. 5) Melaksanakan tindakan.

\section{Pelaksanaan Tindakan}

Dalam tahap ini langkah-langkah pembelajaran dan tindakan mengacu pada perencanaan yang telah dibuat yaitu:

a. Tahap Awal Pembelajaran

1) Guru mengucapkan salam. 2) Guru mengkondisikan siswa ke arah pembelajaran. 3) Guru mengecek kehadiran siswa. 4) Guru melakukan apersepsi dengan mengajukan pertanyaan: "Pernahkah kalian pergi ke Candi Borobudur atau Candi parambanan? Apakah yang kalian lihat di sana?"

b. Tahap Inti Pembelajaran

1) Siswa dibagi ke dalam lima kelompok (tiap kelompok terdiri dari empat sampai dengan lima orang). 2) Seminggu sebelum dilaksanakan pembelajaran tiap kelompok ditugaskan untuk mencari gambar-gambar peninggalan sejarah Hindu-Budha dan Islam melalui media cetak maupun elektronik. 3) Guru mengkondisikan siswa supaya duduk berkelompok. 4) Siswa menyimak panjelasan guru tentang tugas yang harus diselesaikan dalam kelompoknya. 5) Guru memberikan tugas untuk didiskusikan dalam kelompok. 6) Siswa berdiskusi untuk menyelesaikan tugas yang diberikan guru. 7) Setiap kelompok memaparkan hasil tugas yang dikerjakan, menanggapi, 
mempertahankan, menyempurnakan hasil kerja kelompok. 8) Siswa bersama guru membahas yang telah didiskusikan dalam kelompok. 9) Siswa bersama guru menghubungkan materi pelajaran dengan kehidupan sehari-hari mengenai peninggalan-peninggalan sejarah HinduBudha dan Islam. 10) Siswa diberi kesempatan untuk menanyakan apa yang telah dipelajari bersama. 11) Guru melakukan evaluasi.

\section{c. Tahap Akhir Pembelajaran}

1) Guru dan siswa menyimpulkan materi yang telah dipelajari. 2) Melakukan tindak lanjut, guru memberi tugas siswa untuk membaca dan mencari gambar-gambar tentang peninggalan-peninggalan sejarah yang bercorak Hindu-Budha dan Islam lainnya, di luar dari contoh-contoh yang sudah dibahas.

\section{Observasi}

Pada tahap ini terdiri dari pengumpulan data serta mencatat setiap aktivitas siswa dan kinerja guru pada saat pelaksanaan tindakan berlangsung. Observer bertugas mengamati kinerja guru dan aktivitas siswa selama proses pembelajaran berlangsung dengan mengacu pada lembar observasi.

Observasi ini dilakukan oleh peneliti, yaitu dengan mengamati aktivitas siswa dan kinerja guru dalam pembelajaran IPS, mengenai peninggalan-peningkalan sejarah yang bercorak Hindu-Budha dan Islam, dari awal pembelajaran sampai akhir pembelajaran. Hal ini dimaksudkan untuk mengetahui apakah aktivitas siswa dan kinerja guru sudah sesuai dengan apa yang tercantum dalam lembar observasi atau tidak. Dengan demikian, hasil observasi dapat diperbaiki pada siklus berikutnya. Kegiatan observasi lebih difokuskan pada aktivitas diskusi kelompok siswa.

\section{Refleksi}

Refleksi merupakan bagian yang sangat penting untuk memahami dan memberikan makna terhadap proses dan hasil pembelajaran yang terjadi yang dilakukan. Refleksi dilakukan dengan melakukan kegiatan berikut. 1) Mengecek kelengkapan data pengumpulan data yang terjaring selama proses tindakan. 2) Mendiskusikan dan pengumpulan data antara guru, peneliti dan kepala sekolah (pembimbing) berupa hasil nilai siswa, hasil pengamatan, catatan lapangan, dan lain-lain. 3) Penyusunan rencana tindakan berikutnya yang dirumuskan dalam skenario pembelajaran, dengan berdasar pada analisa data dari proses dalam tindakan sebelumnya, untuk memperbaiki proses pembelajaran yang telah dilakukan pada siklus I, untuk menyusun tindakan yang akan dilakukan pada siklus II.

Tempat pelaksanaan penelitian adalah SD Negeri Tegal Mulyo di Kecamatan Laweyan Surakarta. Subjek dalam penelitian ini adalah siswa kelas $V$ SD Negeri Tegal Mulyo. Data dalam penelitian ini diperoleh dari hasil 
Jenny Indrastoeti, SP, \& Hasan Mahfud, Pembelajaran Kooperatif...

observasi, wawancara dan tes yang dilakukan terhadap siswa kelas $V$ SDN Negeri Tegal Mulyo.

\section{HASIL}

\section{Hasil Pembelajaran IPS}

1. Data hasil tes ips dalam aspek keterampilan sosial kelas $\vee$ pada siklus I Dari nilai rata-rata tes IPS dalam aspek keterampilan sosial dapat diketahui bahwa siswa yang mendapatkan nilai 5762 ada 10 siswa, yang mendapat nilai 6368 ada tujuh siswa, yang mendapat nilai 69-74 siswa ada lima siswa, siswa yang mendapatkan nilai 75-80 ada enam siswa, siswa yang mendapat mendapat nilai 8186 ada tiga siswa, dan siswa yang mendapatkan nilai 87-92 ada empat siswa. Rata-rata kelas yang diperoleh adalah 70,98 . Siswa yang mendapatkan nilai di bawah KKM sebanyak 10 siswa atau $28,57 \%$ sedangkan siswa yang mendapatkan nilai di atas KKM ada 25 siswa atau $71,43 \%$.

\section{Data hasil tes IPS dalam aspek}

keterampilan sosial kelas V pada siklus II Dari nilai rata-rata tes IPS dalam aspek keterampilan sosial dapat diketahui bahwa siswa yang mendapatkan nilai 5762 ada 0 siswa, yang mendapat nilai 63-68 ada tujuh siswa, yang mendapat nilai 6974 siswa ada delapan siswa, siswa yang mendapatkan nilai 75-80 ada 14 siswa, siswa yang mendapat mendapat nilai 8186 ada tiga siswa, dan siswa yang mendapatkan nilai 87-92 ada tiga siswa.
Rata-rata kelas yang diperoleh adalah 75,27 . Siswa yang mendapatkan nilai di bawah KKM sebanyak tiga siswa atau $8,57 \%$ sedangkan siswa yang mendapatkan nilai di atas KKM ada 32 siswa atau $91,43 \%$.

\section{Hasil Pengamatan Keterampilan Sosial}

1. Data hasil pengamatan keterampilan sosial siklus I

Berdasarkan hasil observasi keterampilan sosial diperoleh hasil sebagai berikut. Pada pertemuan pertama, siswa yang memperoleh nilai keterampilan sosial kategori cukup sebanyak 27 siswa sedangkan siswa yang memperoleh nilai keterampilan sosial kategori baik ada delapan siswa dari 35 siswa. Sedangkan pada pertemuan kedua meningkat dari delapan siswa menjadi 14 siswa dari 35 siswa atau $40 \%$.

\section{Data hasil pengamatan keterampilan sosial siklus II}

Berdasarkan hasil observasi keterampilan sosial diperoleh hasil sebagai berikut. Pada pertemuan pertama siswa yang memperoleh nilai keterampilan sosial kategori cukup sebanyak 13 siswa sedangkan nilai keterampilan sosial kategori baik ada 22 siswa dari 35 siswa atau sebesar $62,85 \%$. Sedangkan pada pertemuan kedua siswa yang memperoleh nilai keterampilan sosial kategori baik meningkat dari 22 siswa menjadi 29 siswa atau sebesar 82,85\%. 
Tabel 1. Perbandingan Nilai Pengamatan Keterampilan Sosial dan Nilai Tes IPS Siklus I dan Siklus II (bersambung)

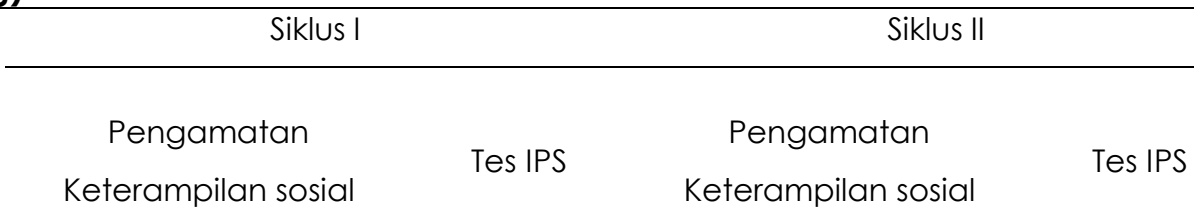

\begin{tabular}{lcccc}
\hline Nilai Terendah & 50,5 & 57 & 58,5 & 63 \\
\hline Nilai Tertinggi & 73,5 & 90 & 84 & 90 \\
\hline Rata-rata Nilai & 62,01 & 70,98 & 72,52 & 75,27 \\
\hline
\end{tabular}

Berdasarkan hasil pada siklus I dan Siklus || maka dapat dilakukan perbandingan ketuntasan tes IPS dan pengamatan keterampilan sosial siswa kelas $\mathrm{V}$ SDN
Tegalmulyo No. 85. Perbandingan ketuntasan siklus | dan siklus || adalah sebagai berikut:

Tabel 2. Perbandingan Ketuntasan Tes IPS dan Keterampilan Sosial Siswa antara Siklus I dan Siklus II

Uraian

Siklus I

Siklus II

\begin{tabular}{lcc}
\hline Rata-rata nilai Tes IPS & 70,98 & 75,27 \\
\hline Rata-rata nilai Keterampilan Sosial & 62,01 & 72,52 \\
\hline Ketuntasan Klasikal Tes IPS & $71,43 \%$ & $91,42 \%$ \\
\hline Ketuntasan Klasikal Keterampilan Sosial & $40 \%$ & $82,85 \%$
\end{tabular}

Berdasarkan pengamatan dan analisis data yang ada, dapat dilihat adanya peningkatan nilai tes IPS, dan hasil pengamatan keterampilan sosial dalam pembelajaran IPS. Peningkatan hasil dari proses pembelajaran IPS adalah siswa dapat lebih mengembangkan keterampilan sosialnya.

\section{PEMBAHASAN}

Berdasarkan hasil pengamatan atau observasi dan hasil tes IPS dapat dilihat adanya peningkatan keterampilan sosial dan peningkatan nilai IPS di kelas $V$ SD Negeri Tegalmulyo No. 85, Laweyan,
Surakarta. Peningkatan keterampilan sosial dalam pembelajaran berdasarkan observasi di antaranya: (1) keterampilan bekerja sama; (2) keterampilan mengendalikan diri; (3) keterampilan berkomunikasi; (4) keterampilan memperoleh dan mengolah informasi.

Adapun deskripsi data hasil penelitian sebagai berikut. Model pembelajaran kooperatif dengan pendekatan experiential learning yang diterapkan pada siklus 1 merupakan model pembelajaran, yang diharapkan dapat menciptakan proses belajar yang lebih 
Jenny Indrastoeti, SP, \& Hasan Mahfud, Pembelajaran Kooperatif...

bermakna. Melalui model ini, siswa belajar tidak hanya belajar tentang konsep materi belaka, hal ini disebabkan karena siswa dilibatkan secara langsung dalam proses pembelajaran untuk dijadikan sebagai suatu pengalaman. Hasil dari proses pembelajaran kooperatif tidak hanya menekankan pada aspek kognitif saja, juga tidak seperti teori behavior yang menghilangkan peran pengalaman subjektif dalam proses belajar. Namun hasil dari penerapan model kooperatif yang diterapkan pada siklus 1 belum terlaksana secara maksimal hal ini dapat terlihat dari hasil kemampuan kognitif dan keterampilan sosial siswa yang masih kurang. Hal ini mungkin disebabkan karena siswa belum terbiasa dengan penggunaan model dan strategi yang baru bagi mereka. Di samping itu keterampilan sosial siswa juga belum maksimal terlihat dalam proses pembelajaran IPS. Hal ini disebabkan karena selama pembelajaran orientasinya lebih berfokus pada hasil belajar pada aspek pengetahuan, sedangkan untuk sikap dan keterampilannya kurang mendapat perhatian optimal.

Kekurangan yang terjadi di siklus 1 telah diperbaiki di siklus 2 dengan mengubah strategi yang lebih mengaktifkan siswa serta memfokuskan pada aspek keterampilan sosial siswa yaitu keterampilan: (1) bekerjasama; (2) mengendalikan diri; (3) berkomunikasi; serta (4) keterampilan memperoleh dan mengolah informasi.
Keterampilan sosial dalam pembelajaran IPS pada siklus II secara klasikal meningkat 19,99\% dari siklus I yaitu $71,43 \%$ menjadi 91,42\% pada siklus II. Nilai terendah dari hasil tes setelah dilaksanakan tindakan siklus II yaitu 63, nilai tertinggi yaitu 90, dan rata-rata nilai secara klasikal meningkat dari siklus I yaitu 70,98 menjadi 75,27 pada siklus II. Hal ini disebabkan pelaksanaan model pembelajaran kooperatif, memiliki keunggulan di antaranya meningkatkan semangat siswa, karena pembelajar aktif, terciptanya suasana belajar yang kondusif dan dinamis serta terbuka dari berbagai arah, dan mendorong serta mengembangkan berpikir kreatif karena siswa partisipatif aktif untuk menemukan sesuatu. Adapun berdasarkan hasil observasi keterampilan sosial diperoleh hasil sebagai berikut. Pada pertemuan pertama siswa yang memperoleh nilai keterampilan sosial kategori baik ada 22 siswa dari 35 siswa atau sebesar 62,85\%. Sedangkan pada pertemuan kedua siswa yang memperoleh nilai keterampilan sosial kategori baik meningkat dari 22 siswa menjadi 29 siswa atau sebesar 82,85\%. Berdasarkan hasil analisis pada tindakan siklus II dapat diketahui adanya peningkatan keterampilan sosial siswa dari tindakan siklus I yaitu $40 \%$ menjadi $82,85 \%$ pada siklus II. Peningkatan keterampilan sosial siswa disebabkan model pembelajaran kooperatif yang secara maksimal diterapkan sebagai perbaikan pada siklus I. 
Berdasarkan hasil penelitian, dapat dijelaskan data perhitungan rata-rata nilai tes keterampilan dari siklus | dan siklus || mengalami peningkatan. Peningkatan terlihat dari siklus I dan siklus II. Pada siklus I siswa yang tuntas diatas KKM $\geq 65$ hanya 25 siswa atau $71,43 \%$, dan pada siklus ॥ siswa yang tuntas diatas KKM $\geq 65$ sebanyak 32 siswa atau $91,42 \%$ dari 35 siswa. Sedangkan ditinjau dari hasil pengamatan, keterampilan sosial siswa juga menunjukkan adanya peningkatan. Pada siklus I siswa yang memperoleh kategori keterampilan sosial baik hanya ada 14 siswa atau 40\%, namun pada siklus Il meningkat menjadi 29 siswa atau $82,85 \%$.

Peningkatan keterampilan siswa berdampak pada peningkatan kemampuan kognitifnya, yang dapat dilihat dari hasil belajar siswa ketika model kooperatif dengan pendekatan experiental learning diterapkan selama dua siklus. Keberhasilan pembelajaran ini disebabkan karena dalam pembelajaran kooperatif siswa dituntut untuk aktif berinteraksi dalam kegiatan kelompok, sehingga kemampuan masing-masing individu akan mendukung kegiatan kelompok. Hal ini seperti yang diungkapkan oleh Com \& Slaby (dalam Syaodih, 2007, p. 50) bahwa keterampilan sosial adalah kemampuan berinteraksi dengan orang lain dalam konteks sosial dengan cara yang spesifik sehingga dapat diterima atau dinilai menguntungkan bagi dirinya atau orang lain.
Keterampilan sosial seseorang terlihat ketika berinteraksi dengan orang lain, khususnya dalam kegiatan yang bersifat kelompok. Seseorang yang memiliki keterampilan sosial yang tinggi akan mampu dalam bekerja kelompok, berpartisipasi dan memberi kontribusi dalam mencapai tujuan kelompok, aktif memberikan saran yang bermanfaat dan berusaha memecahkan permasalahan.

\section{SIMPULAN}

Dari hasil penelitian dan pembahasan yang dikemukakan, disusun simpulan sebagai berikut. Pertama, model pembelajaran kooperatif dengan pendekatan experiental learning dapat meningkatkan keterampilan sosial siswa SDN kelas $V$ Tegal Mulyo Surakarta. Peningkatan keterampilan sosial siswa yang diperoleh melalui kegiatan observasi, berdasarkan hasil analisis pada tindakan siklus II, dapat diketahui adanya peningkatan keterampilan sosial siswa dari tindakan siklus I yaitu $40 \%$ menjadi $82,85 \%$ pada siklus II. Dari hasil observasi peningkatan keterampilan sosial siswa, diikuti juga peningkatan kemampuan pengetahuan IPS siswa, sebagai dampak pengiring (nurturant effect) proses pembelajaran. Persentase ketuntasan secara klasikal pengetahuan IPS siswa meningkat 19,99\% dari siklus I yaitu $71,43 \%$ menjadi 91,42\% pada siklus II. Kedua, desain pembelajaran yang memadai untuk meningkatkan keterampilan sosial siswa SDN kelas $\vee$ Tegal Mulyo Surakarta adalah dengan menggunakan model 
Jenny Indrastoeti, SP, \& Hasan Mahfud, Pembelajaran Kooperatif...

pembelajaran kooperatif dengan pendekatan experinetal learning. Proses pembelajaran dan langkah-langkah pembelajarannya kooperatif dengan pendekatan experiental learning terdiri atas enam fase yaitu: fase 1 menyampaikan tujuan dan memotivasi

\section{REFFERENSI}

Blanks, J. A. (2001). Teaching strategies for the social studies. inquiry valuing, and decision-making. New York: Longman.

Kolb., D. A. (2013). On experiental learning. [online] Tersedia: http://www.infed.org/biblio/b-xplrn.htm

Syaodih, E. (2007). Pengembangan model pembelajaran kooperatif untuk meningkatkan keterampilan sosial. (Disertasi). Bandung: SPs UPI. Tidak dipublikasikan.

Solihatin, E. (2009). Cooperative Learning analisis model pembelajaran IPS. Jakarta: Bumi Aksara.

Fernandes, K., et al.( 1989). Strategi belajar mengajar. Surabaya: Penerbit tidak diketahui.

Jarolimek, J. (2002). Social studies in elementary education. New York: MacMillan Co. Inc.

Sumaatmadja, N. (2006). Konsep dasar IPS. Jakarta: UT.

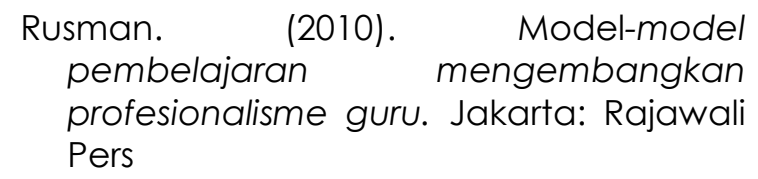
profesionalisme guru. Jakarta: Rajawali Pers
Sasongko, R. N. (2001). Model pembelajaran aksi sosial untuk pengembangan nilai-nilai dan keterampilan sosial. (Disertasi). Bandung: PPs UPI. Tidak dipublikasikan.

Sukmadinata, N. S. (2004). Kurikulum dan pembelajaran kompetensi. Bandung: Kesuma Karya. siswa; fase 2 menyajikan informasi; fase 3 mengorganisasikan siswa ke dalam bentuk kelompok; fase 4 membimbing kelompok bekerja dan belajar; fase 5 evaluasi; dan fase 6 memberikan penghargaan.

Syafruddin. (2001). Penerapan model ATI dalam pembelajaran IPS di SD. (Disertasi). Bandung: PPs UPI. Tidak dipublikasikan. 